\author{
JOURNAL OF MARINE RESEARCH AND TECHNOLOGY \\ journal homepage: https://ojs.unud.ac.id/index.php/JMRT \\ ISSN: $2621-0096$ (electronic); $2621-0088$ (print)
}

\title{
Struktur Komunitas Ikan Karang di Area Ponton Quick Silver, Perairan Toyapakeh, Nusa Penida
}

\author{
Heru Wicaksono $^{\text {a }}$, Elok Faiqoh ${ }^{* a}$, and I Gusti Ngurah Putra Dirgayusa ${ }^{\text {a }}$ \\ ${ }^{a}$ Program Studi Ilmu Kelautan, Fakultas Kelautan dan Perikanan, Universitas Udayana, Bali, Indonesia \\ *Corresponding author, email:elokfaiqoh@unud.ac.id
}

\section{ARTICLE INFO}

\section{Article history:}

Received: June $17^{\text {th }} 2020$

Received in revised form: August $15^{\text {th }} 2020$

Accepted: September $19^{\text {th }} 2020$

Available online: February $28^{\text {th }} 2021$

Keywords:

Community structure

Live coral

Quick Silver utilization area

Reef fish

\section{ABSTRACT}

The availability of coral reefs as habitat is closely related to the exsistence of coral fish resources in the waters. Coral fish resources are very important for tourism, as an object sought after by tourist because of their diverse and charming colors and shapes. Reef fish abundance depends on coral cover. This research was conducted in February 2020. The percentage of coral cover was collected using the Under Water Potography Transect (UPT) method and the visual census method for reef fish communities at five research stations located in the area of the Quick Silver's pontoon, Toyapakeh, Nusa Penida with area of $20.000 \mathrm{~m}^{2}$. Based on the results, the diversity index in the first data collection ranged from 3.18-3.76, which means the diversity isin the high category. On the other hand, the diversity index in the second data collections tends to decrease in the range of 2.66-3.40, which means that the diversity is in the medium to high category. The uniformity index for the first and second data collection falls into the category of distressed communities. The dominances index on the two data found inj the low category. From this research, it was also found that the percentage of live coral cover in the area of use of the Quick Silver pontoon ranged from $0.08 \%$ to $17.32 \%$, which means that all research stations were classified as bad. These results indicate that the presence of reef fish is not only caused by live corals but also by anthropogenic activities of the pontoon, such as manual feeding by visitors. This condition applies to reef fish with omnivore eating behavior, one of which is the Pomacentridae family of the major fish group. These anthropogenic activities can change the composition of reef fish communities and increase abundance.

2021 JMRT. All rights reserved.

\section{Pendahuluan}

Ekosistem terumbu karang didefinisikan sebagai tempat hidup dari berbagai jenis biota laut (Arham, 2013). Penyusunnya sebagian besar meliputi karang keras, serta memiliki fungsi biologi dan fisika (Arham, 2013). Serta sebagai area mencari makan (feeding), bertelur (spawning) dan asuhan (nursery) bagi ikan karang (Rembet et al., 2011).

Spesies ikan karang di Indonesia sebanyak 2057 spesies yang sudah ditemukan dan terbagi menjadi 113 famili serta terdapat 6 famili indikator yang merepresentasikan ikan karang di perairan Indonesia, antara lain Achanturidae, Chaetodonidae, Labridae, Pomachantidae, Pomacentridae dan Scaridae (Allen \& Adrim, 2003). Sumberdaya ikan karang secara ekonomis sangat penting bagi dunia pariwisata, sebagai objek yang dicari oleh para wisatawan dikarenakan bentuk dan warnanya yang beraneka ragam (Rudi \& Inmudi, 2010), sehingga perlu dilakukan pengelolaan secara terencana dengan baik, terkendali dan bijaksana yang berfungsi untuk menjaga kestabilan sumberdaya ikan karang, karena pada era modern kini banyak perusahaan besar yang memanfaatkan ponton sebagai tempat untuk mengakomodasi kegiatan wisata bahari.
Ponton merupakan sebuah kapal apung yang berdiam di permukaan laut dan mampu menahan beban berat serta dapat mengapung sendiri (Wu \& Shih, 1998). Ponton Quick Silver terletak di perairan Nusa Penida yang merupakan sebuah pulau di Provinsi Bali, bagian dari sunda kecil ekoregion dan masuk kedalam area segitiga karang. Wilayah perairan Nusa Penida adalah salah satu perairan area perlindungan laut di Kabupaten Klungkung yang memiliki ciri khas perairannya yakni berpasir putih dan memiliki keberagaman biota laut (Pemerintah Daerah Klungkung, 2010), sehingga bertumbuhnya pariwisata khususnya pada bidang bahari di Nusa Penida tidak lepas dari lokasinya yang sangat strategis serta mudah dijangkau.

Quick Silver merupakan salah satu dari 3 perusahaahn besar yang memiliki ponton di Kawasan Konservasi Perairan Nusa Penida (Dermawan et al., 2014), yang memiliki area pemanfaatan sendiri seluas $20.000 \mathrm{~m}^{2}$ untuk pengelolaan konservasi perairan Quick Silver, serta digunakan untuk sarana kegiatan olahraga air bagi wisatawan domestik dan mancanegara. Secara umum kondisi komunitas ikan karang di perairan Nusa Penida berada pada level baik dengan ditemukannya 576 spesies ikan karang dengan 68 famili ika n karang (Allen \& Erdmann, 2009). Studi di Toyapakeh yang dilakukan oleh Desvianti \& Choesin, (2015) menyatakan bahwa komunitas ikan karang berada pada kondisi sedang dengan 
tekanan ekologi tinggi. Menurut Syakur (2000), di area ponton Toyapakeh, Nusa Penida mengenai komunitas ikan karang menyatakan bahwa kondisi ikan karang berada pada kondisi baik dengan tekanan ekologi yang rendah. Penelitian ini bertujuan untuk mengetahui persentase tutupan terumbu karang dan komunitas ikan karang di area ponton Quick Silver, perairan Toyapakeh, Nusa Penida.

\section{Metode}

\subsection{Waktu dan lokasi penelitian}

Penelitian ini dilaksanakan pada Bulan Februari 2020 di area ponton Quick Silver Desa Toyapakeh, Kecamatan Nusa Penida, Kabupaten Klungkung, Provinsi Bali (Gambar 1). Penentuan stasiun penelitian berdasarkan area pemanfaatan Quick Silver.

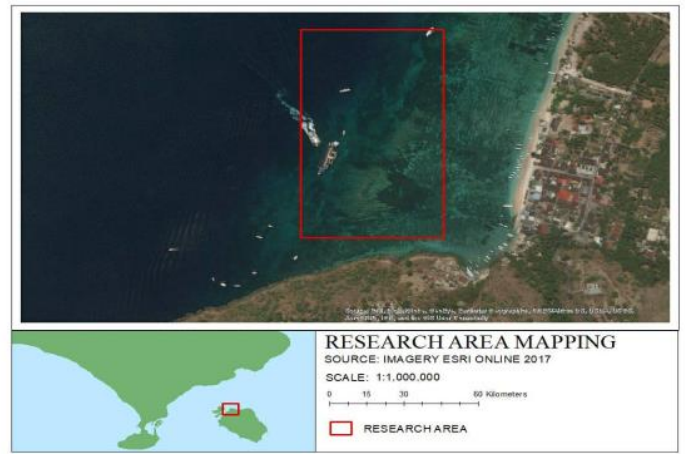

Gambar 1. Lokasi stasiun penelitian

Area penelitian meliputi stasiun 1 bawah ponton, stasiun 2 jet ski, stasiun 3 kapal sandar, stasiun 4 snorkling dan stasiun 5 subsea, yang merupakan kawasan wisata bahari yang dimana terdapat wisata kapal selam, wisata snorkeling dan diving, wisata jet ski dan daerah bersandar boat untuk wisatawan.

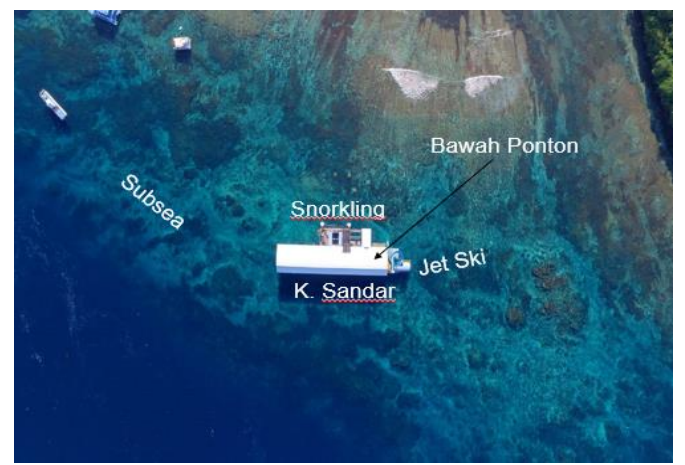

Gambar 2. Area pemanfaatan Quick Silver

Tabel 1. Titik koordinat lokasi penelitian

\begin{tabular}{lcc}
\hline \multicolumn{1}{c}{ Nama stasiun } & Longitude & Latitude \\
\hline Bawah ponton & -8.68143 & 115.48394 \\
Kapal sandar & -8.68217 & 115.48405 \\
Jet ski & -8.67937 & 115.48557 \\
Snorkling & -8.67900 & 115.48454 \\
Subsea & -8.68199 & 115.483231 \\
\end{tabular}

\subsection{Metode Penelitian}

\subsubsection{Pengambilan tutupan terumbu karang}

Metode yang digunakan dalam pengambilan data persentase tutupan terumbu karang adalah metode pengambilan foto bawah air UPT (Underwater Photography Transect) (Giyanto et al., 2010; Giyanto, 2012a; Giyanto, 2012b). Metode UPT adalah metode pengambilan data terumbu karang dengan memanfaatkan kemajuan teknologi.

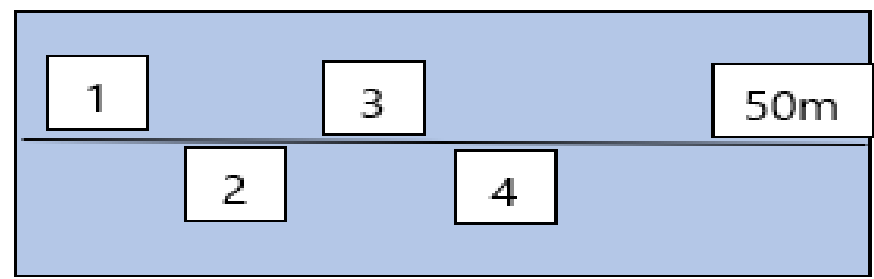

Gambar 3. Ilustrasi metode UPT (Giyanto, 2014)

Pengambilan data pada saat penyelaman dengan cara memotret frame dengan menggunakan kamera anti air (housing) dan selanjutnya diidentifikasi menggunakan software CPCe (Coral Point Count with Excel Extension).

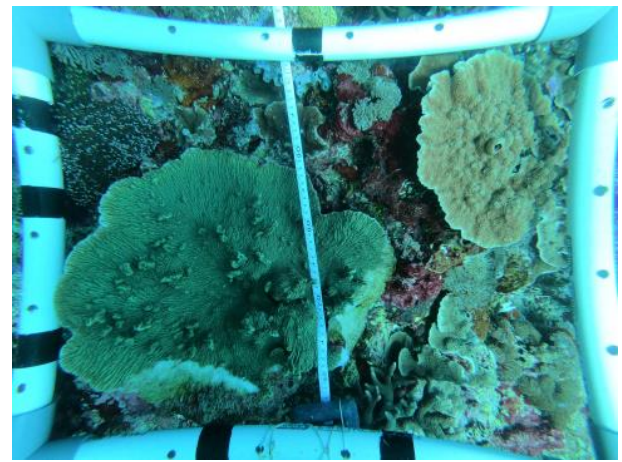

Gambar 4. Fotografi bawah air

Pengolahan data dilakukan pada setiap foto atau frame dengan menggunakan pemilihan titik sejajar yang ditujukan agar titik tersebar diseluruh frame dan tidak terfokus di satu sudut. Jumlah titik yang digunakan sebanyak 30 titik untuk setiap foto, dan ini sudah representatif untuk memeroleh persentase tutupan terumbu karang (Giyanto et al., 2010).

\subsubsection{Pengambilan data ikan karang}

Pengambilan data ikan karang digunakan metode sensus visual (Visual Census Method) (Hodgson, 1999). Pada stasiun pengamatan ditarik transek garis (roll meter) sepanjang 50 meter di stasiun penelitian. Pendataan ikan karang memperkirakan jarak 2,5 m pada sisi kiri dan kanan transek (Hodgson, 1999). Pengambilan data ikan karang dilakukan sebanyak 2 kali pengambilan dalam kurun waktu 1 bulan untuk diketahui struktur komunitas.

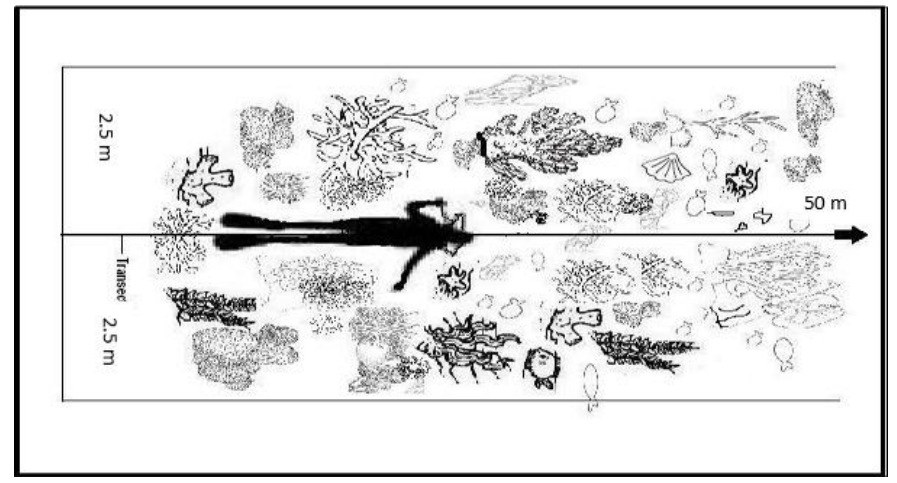

Gambar 5. Pengambilan data ikan karang 


\subsection{Analisis data}

\subsubsection{Persentase tutupan terumbu karang}

Menurut Giyanto et al., (2010), pengolahan data terumbu karang untuk memperoleh persentase tutupan terumbu karang berdasarkan hasil foto bawah air menggunakan rumus sebagai berikut :

Tutupan Karang $=\frac{\text { fwwiah titik hategori tersebut }}{\text { jumlah titik acak }} \times 100 \%$

Untuk memperoleh total persentase tutupan terumbu karang digunakan rumus sebagai berikut (Giyanto et al., 2010):

Tutupan Karang $=\frac{\text { jumlah tutupankategori }}{\text { Jumlah frame }} \times 100 \%$

Tabel 2. Kriteria terumbu karang

\begin{tabular}{cc}
\hline Kondisi & Kategori \\
\hline Buruk & $(0 \%-25 \%)$ \\
Sedang & $(25 \%-50 \%)$ \\
Baik & $(50 \%-75 \%)$ \\
Sangat baik & $(75 \%-100 \%)$
\end{tabular}

Sumber: KEPMENLH No. 4 Tahun 2001

\subsubsection{Kelimpahan ikan karang}

Kelimpahan ikan karang dihitung menggunakan rumus sebagai berikut:

$$
N=\frac{n i}{A}
$$

Keterangan:

$\begin{array}{ll}\mathrm{N} & : \text { Kelimpahan individu } \\ \mathrm{Ni} & : \text { Jumlah spesies } \\ \mathrm{A} & \text { :Luas area }\end{array}$

\subsubsection{Indeks keanekaragaman ( $\left.H^{\prime}\right)$}

Keanekaragaman ikan karang dihitung berdasarkan rumus berikut:

$$
H^{r}=-\sum_{i=1}^{n} p i \ln p i
$$

Keterangan:

H' :Indeks keanekaragaman

$\mathrm{Pi}$ :Perbandingan jumlah individu spesies ke-i dan n

Tabel 3. Kategori keanekaragaman

\begin{tabular}{ccc}
\hline No & H' & Kategori \\
\hline 1 & $\mathrm{H}^{\prime}<2.0$ & Rendah \\
2 & $2.0<\mathrm{H}^{\prime}<3.0$ & Sedang \\
3 & $\mathrm{H}^{\prime}>3.0$ & Tinggi
\end{tabular}

Sumber: Hukom (1998)

\subsubsection{Indeks keseragaman $(E)$}

Indeks keseragaman ikan karang dihitung menggunakan rumus sebagai berikut:

$$
\mathrm{E}=\frac{H^{x}}{n}
$$

Keterangan:

$\begin{array}{ll}\mathrm{E} & \text { :Indeks keseragaman } \\ \mathrm{H} & \text { :Indeks keanekaragaman } \\ \mathrm{N} & \text { :Jumlah spesies }\end{array}$

Tabel 4. Kategori keseragaman

\begin{tabular}{ccc}
\hline No & $\mathbf{E}$ & Kategori \\
\hline 1 & $0.00<\mathrm{E} \leq 0.50$ & Tertekan \\
2 & $0.50<\mathrm{E} \leq 0.75$ & Labil \\
3 & $0.75<\mathrm{E}, 1.00$ & Stabil
\end{tabular}

Sumber: Odum, (1971)

\subsubsection{Indeks dominansi}

Menurut Odum, (1971), indeks dominansi dihitung menggunakan rumus sebagai berikut:

$$
\mathrm{D}=\sum_{i=1}^{\mathrm{n}} p i^{2}
$$

Keterangan:

D :Indeks dominansi

Pi :Jumlah individu spesies

Tabel 5. Kategori dominansi

\begin{tabular}{ccc}
\hline No & D & Kategori \\
\hline 1 & $0.00<\mathrm{D} \leq 0.50$ & Rendah \\
2 & $0.50<\mathrm{D} \leq 0.75$ & Sedang \\
3 & $0.75<\mathrm{D} \leq, 1.00$ & Tinggi
\end{tabular}

\section{Sumber: Odum, (1971)}

\section{Hasil dan Pembahasan}

\subsection{Hasil}

\subsubsection{Gambaran umum stasiun penelitian}

Keberadaan Ponton Quick Silver di Toyapakeh, Nusa Penida merupakan salah satu destinasi wisata bahari yang terletak di Kabupaten Klungkung. Secara geografis ponton Quick Silver terletak pada posisi $8^{\circ} 68^{\prime} 14^{\prime} 258^{\prime \prime}$ LS dan $115^{\circ} 48^{\prime} 39^{\prime} 41$ BT. Quick Silver sendiri memiliki area pemanfaatan seluas $20.000 \mathrm{~m}^{2}$ untuk pengelolaan konservasi, yang dimana area tersebut mengelilingi ponton dan secara umum di area pemanfaatan terdapat hamparan ekosistem terumbu karang alami maupun terumbu karang buatan, sehingga terdapat beberapa tempat untuk wisata bahari diantaranya wisata jet ski, wisata semi kapal selam, snorkling dan diving. Selain itu ponton Quick Silver juga digunakan untuk bersandarnya kapal (Cruise) serta kegiatan memberi makan ikan (feeding) oleh wisatawan yang berkunjung. 
Tabel 6. Kualitas perairan

\begin{tabular}{clccccc}
\hline No & Parameter & $\begin{array}{c}\text { Bawah } \\
\text { Ponton }\end{array}$ & $\begin{array}{l}\text { Jet } \\
\text { Ski }\end{array}$ & $\begin{array}{c}\text { Kapal } \\
\text { Sandar }\end{array}$ & Snorkling & Subsea \\
\hline 1 & Suhu (C) & 23 & 23 & 23 & 23 & 23 \\
2 & $\mathrm{pH}$ & 8,1 & 8,2 & 8,1 & 8,2 & 8,2 \\
3 & $\begin{array}{l}\text { Salinitas } \\
(\mathrm{ppt})\end{array}$ & 34 & 35 & 34 & 35 & 35 \\
4 & $\begin{array}{l}\text { Kecerahan } \\
(\%)\end{array}$ & 100 & 100 & 100 & 100 & 100 \\
5 & $\begin{array}{l}\text { Arus } \\
(\text { Cm/s) }\end{array}$ & 40,03 & 40,56 & 42,33 & 22,55 & 40,89 \\
6 & $\begin{array}{l}\text { Kedalaman } \\
(\mathrm{m})\end{array}$ & 7 & 6 & 7 & 5 & 8 \\
\hline
\end{tabular}

Sumber: Diambil data oleh penulis

\subsubsection{Tutupan terumbu karang}

Kondisi penutupan terumbu karang di setiap stasiun penelitian yang menggunakan metode UPT dibagi berdasarkan life form. Kategori tersebut antara lain Coral, Dead Coral, Algae, NonCoral, Other dan Abiotic. Adapun hasil penelitian yang dilakukan dapat dilihat pada tabel 7 berikut :

Table 7. Persentase tutupan terumbu karang

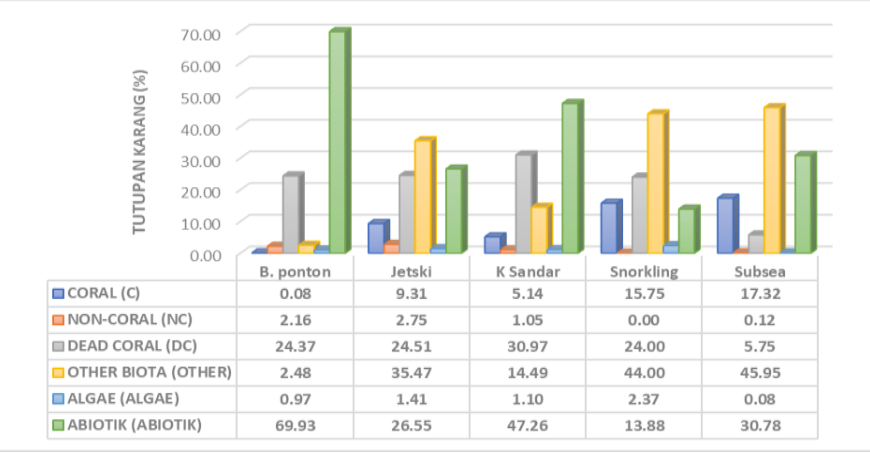

Pada tabel 7 diatas, tutupan terumbu karang dilokasi penelitian didominasi oleh 2 komponen yakni abiotik dan other. Abiotik tertinggi dari kelima stasiun terdapat pada stasiun bawah ponton sebesar $69,93 \%$ dibanding stasiun lainnya. Abiotik di area penelitian didominasi oleh rubble. Selain abiotik juga terdapat unsur other yang mendominasi di area penelitian. Other tertinggi terdapat pada stasiun subsea sebesar $45,95 \%$ dibanding stasiun lainnya. Other yang dimaksudkan yaitu softcoral, sponge dan zoanthid.

\subsubsection{Persentase famili ikan karang di kelima stasiun penelitian}

Dari gambar 7 dibawah didapatkan bahwasannya, persentase famili ikan karang tertinggi di semua stasiun adalah famili pomacentridae yang dikomposisikan pada gambar diatas. Famili Pomacentridae memperoleh persentase tertinggi yang terdapat pada stasiun jet ski dengan persentase famili sebesar 43,09\% dimana spesies mendominasi yaitu Chrysiptera parasema sebanyak 31,25 individu ikan karang. Persentase tertinggi kedua dari famili Chaetodonidae sebesar $19,53 \%$ dan persentase terendah dari famili Monachantidae dan Ostraciidae dengan masing-masing sebesar 0,20\%.

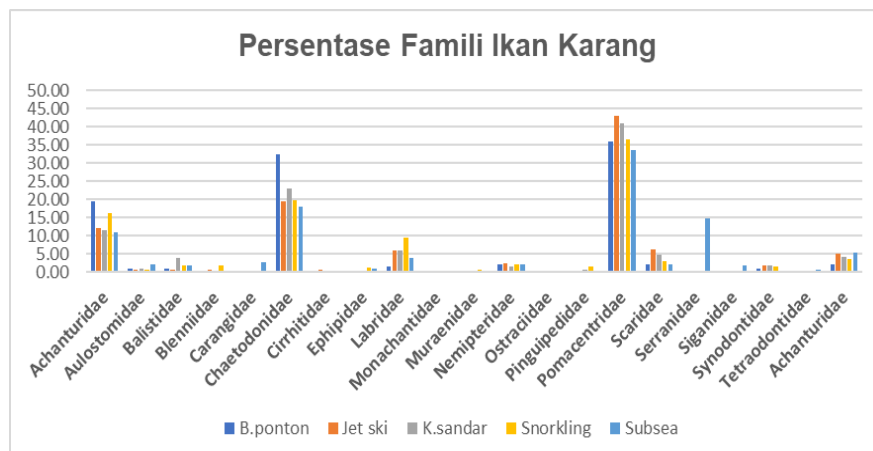

Gambar 6. Persentase famili ikan karang 3.1.4. Kelimpahan ikan karang

Kelimpahan ikan karang dicari untuk mengetahui jumlah ikan karang yang ditemukan pada stasiun penelitian. Adapun hasil kelimpahan pada stasiun penelitian yakni sebagai berikut:

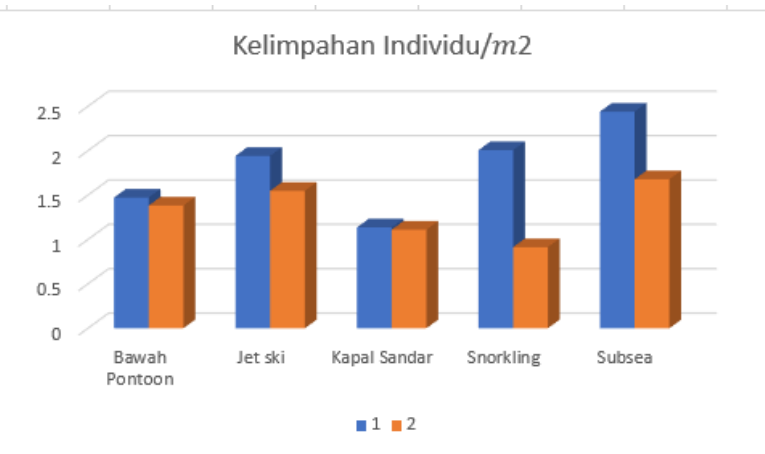

Gambar 7. Kelimpahan ikan karang

Pada gambar 7 diatas, didapatkan bahwasannya kelimpahan ikan karang pada pengambilan data pertama lebih tinggi dari pada pengambilan data kedua. Dengan kelimpahan tertinggi pada pengambilan data pertama di stasiun subsea 2,44 individu $/ m^{2}$ dan kelimpahan terendah terdapat pada stasiun kapal sandar sebesar $1,14 \mathrm{individu} / \mathrm{m}^{2}$. Kemudian pengambilan data kedua kelimpahan tertinggi terdapat pada stasiun subsea sebesar 1,68 individu $/ m^{2}$ dan kelimpahan terendah terdapat pada stasiun snorkeling sebesar 0,95 individu $/ m^{2}$.

\subsubsection{Komunitas ikan karang}

Struktur komunitas ikan karang merupakan salah satu faktor keseimbangan ekosistem di dasar perairan. Berdasarkan hasil pengolahan diperoleh hasil sebagai berikut:

Tabel 8. Struktur komunitas ikan karang

\begin{tabular}{lcccccc}
\hline \multicolumn{1}{c}{ Stasiun } & \multicolumn{2}{c}{$\mathrm{H}^{\prime}$} & \multicolumn{2}{c}{$\mathrm{E}$} & \multicolumn{2}{c}{$\mathrm{D}$} \\
\hline Bawah Pontoon & 3.18 & 2.66 & 0.10 & 0.01 & 0.05 & 0.09 \\
Jet ski & 3.52 & 2.93 & 0.07 & 0.12 & 0.04 & 0.07 \\
Kapal Sandar & 3.36 & 2.97 & 0.08 & 0.13 & 0.04 & 0.06 \\
Snorkling & 3.66 & 3.04 & 0.06 & 0.01 & 0.03 & 0.07 \\
Subsea & 3.76 & 3.40 & 0.07 & 0.08 & 0.03 & 0.04 \\
\hline & 1 & 2 & 1 & 2 & 1 & 2 \\
\hline
\end{tabular}

Sumber: Dihitung oleh penulis

Berdasarkan tabel 8 diatas, indeks keanekaragaman tertinggi pada pengambilan data pertama dan kedua tedapat pada stasiun subsea sebesar 3,76 dan 3,40 yang artinya masuk kedalam 
kategori keanekaragaman tinggi. Sedangkan indeks keanekaragaman terendah pada 2 minggu pertama dan kedua terdapat pada stasiun bawah ponton yakni sebesar 3,18 dan 2,66 yang artinya indeks keanekaragaman masuk kedalam kategori tinggi dan sedang. Indeks keseragaman pada semua stasiun penelitian pada 2 minggu pertama maupun kedua memperoleh hasil antara 0,01 - 0,13 yang berarti masuk kedalam kategori komunitas tertekan. Indeks dominansi pada kelima stasiun pada 2 minggu pertama dan kedua mendapatkan hasil antara 0,03 - 0,09 yang berarti masuk kedalam kategori rendah.

\subsection{Pembahasan}

Mengacu pada KEPMENLH No. 4 Tahun 2001 mengenai kriteria Baku Kerusakan Terumbu Karang, tutupan terumbu karang di kelima stasiun penelitian masuk kedalam kategori buruk karena hasil persentase tutupan karang (tabel 7) menunjukkan dibawah $25 \%$. Dilihat pada stasiun penelitian bawah ponton dan kapal sandar bahwasannya pada kedua stasiun tersebut memperoleh tutupan karang terkecil dibanding stasiun lainnya dengan yang mendominasi yaitu abiotik (silk, sand, rock, rubble), hal ini diduga akibat adanya aktifitas antropogenik dari ponton termasuk juga kapal (cruise) yang bersandar setiap hari yang secara langsung menghalagi sinar matahari, sehingga menyebabkan perkembangan karang tidak optimal dan menyebabkan tingginya abiotik (Syakur, 2000), serta diduga akibat padatnya lalu lintas dari pada fast boat yang keluar masuk pelabuhan penyeberangan yang terletak di perairan Toyapakeh.

Dilihat dari tabel 7, stasiun tertinggi tutupan karangnya yaitu stasiun subsea sebesar 17,32\%, selanjutnya stasiun snorkeling sebesar $15,75 \%$ dan stasiun jet ski sebesar 9,31\%, dengan lifeform yang mendominasi yaitu other biota (sponge, soft coral zoanthid and anemone). Tingginya kepadatan karang lunak dipengaruhi oleh kedalaman dimana intensitas cahaya matahari yang memasuki perairan baik untuk partumbuhan dan makanan karang lunak (Mardianto et al., 2016).

Berdasarkan gambar 6, persentase famili ikan karang tertinggi di kelima stasiun penelitian yaitu dari famili Pomacentridae, hal ini diduga bahwa ikan karang dengan famili Pomacentridae mendapatkan asupan makanan dari aktifitas antropogenik ponton yaitu pemberian pakan oleh wisatawan yang menjadi pengganti dari rendahnya tutupan karang di kelima stasiun penelitian. Hal ini sejalan dengan pernyataan Syakur (2000), bahwa di area ponton sering dilakukan aktifitas pemberian pakan ikan karang oleh wisatawan sehingga berkumpulnya ikan karang di area ponton. Kondisi ini berlaku bagi sebagian besar kelompok ikan target, indikator dan mayor, seperti Achanturidae, Chaetodonidae dan Pomacentridae. Penelitian sebelumnya yang dilakukan oleh Allen \& Erdmman (2009), bahwa persentase famili tertinggi yakni dari keluarga Labridae dan dipperoleh keluarga Pomacentridae di urutan persentase terbanyak kedua.

Berdasarkan hasil kelimpahan ikan karang di kelima stasiun penelitian (gambar 7), pada pengambilan data pertama kelimpahan ikan karang di kelima stasiun lebih tinggi dari pada kelimpahan ikan karang pada pengambilan data kedua. Hal ini diduga karena pada pengambilan data pertama di lapangan, kegiatan pemberian pakan (feeding) oleh wisatawan masih dilakukan sehingga ikan karang tetap mencari makan di area ponton, sedangkan pada pengambilan data kedua kegiatan pemberian pakan (feeding) tidak dilakukan dikarenakan sepinya wisatawan yang datang di ponton. Kelimpahan ikan karang tertinggi terdapat pada stasiun subsea pada pengambilan data pertama maupun pengambilan data kedua. Hal ini dikarenakan tingginya persentase tutupan karang pada stasiun tersebut dibandingkan dengan stasiun lainnya. Hal ini sejalan lurus dengan pernyataan dari Ahmad (2013), bahwasannya faktor-faktor yang mempengaruhi kehadiran ikan (komunitas dan kelimpahan) di suatu komunitas terumbu karang yaitu tinggi rendahnya persentase terumbu karang di suatu perairan.

Keanekaragaman (H') pada kelima stasiun pada pengambilan data pertama lebih tinggi daripada pengambilan data kedua. Keanekaragaman tertinggi terdapat pada stasiun subsea pada pengambilan data pertama, hal ini dikarenakan tutupan karang pada stasiun subsea memperoleh nilai tertinggi dibandingkan dengan stasiun lainnya. Terjadi penurunan nilai keanekaragaman pada pengambilan data kedua, hal ini diduga pada saat pengambilan data kedua pemberian pakan tidak dilakukan karena sepinya wisatawan sehingga mengakibatkan turunnya nilai keanekaragaman, tetapi tetap dalam kategori keanekaragaman tinggi. Hal ini sejalan dengan pernyataan Ahmad (2013) bahwasannya tingginya persentase karang hidup memberikan ruang perlindungan bagi ikan karang. Nilai keanekaragaman stasiun bawah ponton merupakan nilai terendah dibandingkan dengan stasiun lainnya diduga karena tingginya unsur abiotik (rock, sand, rubble dan silk) hingga mencapai 69,93\%, sehingga ikan yang berada pada stasiun tersebut kurang mendapatkan asupan dari terumbu karang dan yang bertahan adalah ikan karang yang hanya mengandalkan makanan dari kegiatan dan aktifitas ponton yaitu pemberian pakan (feeding). Ikan karang yang bertahan adalah ikan yang bertipe makan omnivora seperti Pomacentridae dari kelompok ikan mayor. Hal ini sejalan dengan pernyataan Desvianti \& Choesin, (2015) bahwa di perairan Toyapakeh ikan bertipe makan omnivora seperti Pomacentridae banyak dijumpai dikarenakan pemberian pakan dapat mengubah komposisi komunitas ikan dan meningkatkan kelimpahan.

Keseragaman (E) di kelima stasiun penelitian masuk kedalam kategori komunitas tertekan, hal ini dikarenakan beragamnya ikan karang pada kelima stasiun penelitian dan juga faktor tekanan ekologi yang tinggi (Syakur, 2000). Indeks dominansi (D) di kelima stasiun pada pengambilan data pertama maupun kedua tergolong rendah yang artinya tidak ada spesies yang mendominasi di kelma stasiun.

Menurut Rani et al., (2010), menyatakan bahwa ikan karang adalah makhluk hidup yang memiliki keterkaitan dengan terumbu karang dimana persentase tutupan yang tinggi akan membuat kelimpahan ikan karang menjadi tinggi. Akan tetapi pada studi kasus di area pemanfaatan ponton Quick Silver, terlihat kelimpahan ikan karang tergolong tinggi, meskipun persentase tutupan terumbu karangnya tergolong buruk, hal ini disebabkan oleh aktifitas antropogenik ponton yaitu pemberian pakan oleh wisatawan, sehingga ikan karang berkumpul untuk mencari makan di perairan di sekitar ponton (Syakur, 2000).

\section{Kesimpulan}

Adapun kesimpulan yang diperoleh dari penelitian struktur komunitas ikan karang di area Ponton Quick Silver yaitu persentase tutupan terumbu karang yang mengacu pada KEPMENLH No. 4 Tahun 2001 tentang kriteria baku kerusakan terumbu karang, bahwa pada kelima stasiun penelitian masuk kedalam kategori "buruk" karena persentase tutupan terumbu karang pada kelima stasiun berada dibawah $25 \%$, hal ini diduga akibat aktifitas antropogenik dari ponton, serta faktor aktifitas kapal cepat yang keluar masuk pelabuhan Toyapakeh. Pada komunitas ikan karang, indeks keanekaragaman di kelima stasiun pada pengambilan data pertama berkisar antara 3,18 - 3,76 yang artinya masuk kedalam kategori tinggi, sedangkan keanekaragaman pada pengambilan data kedua berkisar antara 2,66 - 3,40 yang artinya masuk kedalam kategori sedang hingga 
tinggi. Hal ini diduga dikarenakan aktifitas antropogenik ponton yaitu fish feeding sehingga perairan tersebut menjadi salah satu lokasi mencari makan bagi ikan karang bertipe makan omnivora seperti Pomacentridae. Rendahnya nilai indeks keseragaman di kelima stasiun pada pengambilan data pertama dan kedua berkisar antara 0,01 - 0,13 dimana di kelima stasiun penelitian masuk kedalam kategori komunitas tertekan. Indeks dominansi di kelima stasiun penelitian pada pengambilan data pertama dan kedua berkisar antara 0,03 - 0,09 dimana kelima stasiun penelitian masuk kedalam kategori rendah

\section{Ucapan terima kasih}

Terima kasih penulis ucapkan dan sampaikan kepada Frederik Titaheluw, Kadek Yunarta. Bagus Prakoso selaku Kepala Departemen Konservasi Perairan Quick Silver dalam pengambilan data di lapangan, seluruh pegawai ponton Quick Silver Nusa Penida yang terlibat dan Fakultas Kelautan dan Perikanan Universitas Udayana atas fasilitas yang telah diizinkan dan diberikan kepada penulis.

\section{Daftar Pustaka}

[KEPMENLH] Keputusan Menteri Negara Lingkungan Hidup No. 4 Tahun 2001 Tentang: Kriteria Baku Kerusakan Terumbu Karang.

Ahmad. 2013. Sebaran dan Keanekaragaman Ikan Target Pada Kondisi dan Topografi Terumbu Karang di Pulau Samatellulompo Kabupaten Pangkep. Skripsi. Makassar: Universitas Hasanuddin. 60 hal.

Allen GR, Erdmann M. 2009. Reef Fish of Nusa Penida, Indonesia. Final Report to Conservation International, Arlington.

Allen GR, Adrim M. 2003. Coral Reef Fishes of Indonesia. Zoological Studies. 42. (1):1-72

Arham M. 2013. Status ekologi ikan karang kaitannya dengan tutupan makroalga dan terumbu karang di pulau-pulau kecil kabupaten polman [tesis]. Makassar: Program Pasca Sarjana Universitas Hasanuddin.

Dermawan A, Bahri S, Suraji. 2014. Status Pengelolaan Efektif Kawasan Konservasi Perairan, Pesisir dan Pulau-Pulau Kecil di Indonesia. Jakarta: KKP RI. $327 \mathrm{Hlm}$

Desvianti D, Choesin DN. 2015. Comparison between coral reef ecosystem in the marine tourism zone and core zone in Toyapakeh, Nusa Penida. Institut Teknologi Bandung

Giyanto, Iskandar BH, Soedharma D, Suharsono. 2010. Effisiensi dan akurasi pada proses analisis foto bawah air untuk menilai kondisi terumbu karang. Oseanologi dan Limnologi di Indonesia Vol. 36 (1): 111-130.

Giyanto, Manuputty AEW, Abrar M, Siringoringo RM. 2014. Panduan Monitoring Kesehatan Terumbu Karang. Jakarta: COREMAP CTI LIPI.

Giyanto. 2012a. Kajian tentang panjang transek dan jarak antar pemotretan pada penggunaan metode transek foto bawah air. Oseanologi dan Limnologi di Indonesia Vol. 38 (1): 1-18.

Giyanto. 2012b. Penilaian kondisi terumbu karang dengan metode transek foto bawah air. Oseanologi dan Limnologi di Indonesia Vol. 38 (3): 377-390.

Hodgson G. 1999. A global assessment of human effects on coral reefs. Marine Pollution Bulletin Vol. 38 (5): 345-355.

Hukom FD. 1998. Ekostruktur dan organisasi spasial-temporal ikan karang di perairan teluk ambon [tesis]. Bogor: Program Pasca Sarjana Institut Pertanian Bogor.

Mardianto, Nur AI, Ramli M. 2016. Studi ekologi bamboolaut (Isis hippuris) di perairan tanjung Tiram Kecamatan Maramo Utara Kabupaten Konawe Selatan. Kendari: Fakultas Perikanan dan Ilmu Kelautan, Universitas Halu Oleo. Jurnal Manajemen Sumberdaya Perairan, 1(3): 323 - 332

Odum EP. 1971. Fundamental of Ecology. Philadelphia: WB Saunders Company. Philadelphia and London. 564 p.

Pemerintah Daerah Klungkung. 2010. "Profil Kawasan Konservasi Perairan (KKP) Nusa Penida, Kabupaten Klungkung- Provinsi Bali.”

Rani C, Burhanuddin AI, Atjo AA. 2010. Sebaran dan Keanekaragaman Ikan Karang di Pulau Barrangloppo: Kaitannnya Dengan Kondisi dan Kompleksitas Habitat. Fakultas Kelautan dan Imu Kelautan, Universitas Hasanuddin. Makassar. 12 hal.
Rembet UN, Boer M, Bengen DG, Fahrudin A. 2011. Struktur komunitas ikan target di terumbu karang Pulau Hogow dan Putus-putus, Sulawesi Utara. Jurnal Perikanan dan Kelautan Tropis Vol. 7 (2): 1-6.

Rudi E, Muchsin I. 2010. Ikan Karang Perairan Aceh dan Sekitarnya. Bandung: Lubuk. Agung. $216 \mathrm{hlm}$.

Syakur A. 2000. Komunitas ikan karang pada ekosistem terumbu karang ponton Bodong dan Toyapakeh, Nusa Penida, bali. [skripsi]. Bogor: Institut Pertanian Bogor. $67 \mathrm{hlm}$.

Wu JS, Shih PY. 1998. Moving-load-induced vibrations of a moored floating bridge. Computers and Structures Vol. 66 (4): 435-61. 